\title{
全方向形回転跳躍球形ロボットの開発と制御
}

\section{Development and control of all direction jumping and rolling spherical robot}

\author{
Jun FUJIOKA ${ }^{* 1}$, Seigo NAKAMURA ${ }^{* 2}$ and Hiroaki SEKI ${ }^{* 2}$ \\ ${ }^{* 1}$ Department of Mechanical Engineering, Ishikawa National College of Technology \\ ta-1 Kitacyujo, Tsubata-machi, Kahoku-gun, Ishikawa 929-0392, Japan \\ ${ }^{* 2}$ School of Mechanical Engineering, College of Science and Engineering Kanazawa University \\ Kakuma-machi, Kanazawa-shi, Ishikawa 920-1192, Japan
}

\section{Received 18 March 2015}

\begin{abstract}
This paper describes new mechanisms, principle, control methods and experimental results of the jumping and rolling spherical robot which has not any projection. The robot consists of spherical mono wheel, internal drive unit and internal jumping mechanism using a compression coil spring. Straight running is performed by movement of the centroid when the drive unit moves along the inner surface of the spherical wheel, and turning is performed by rotating of the drive unit and friction torque of the spherical wheel with the ground. Theoretical result of straight running and turning movement coincide with experimental results of the robot. Jumping movement is caused by impact force between whole internal mechanisms and the inner surface of the spherical wheel by releasing stored energy in the spring. It was confirmed experimentally that the new robot has high jumping faculty in addition to the basic movement of spherical robot. Furthermore, jumping in any oblique direction is performed by control the posture of internal mechanism, and it becomes possible for the robot to go up the steps of stairs in this way. Therefore, we conclude that the all direction jumping and rolling spherical robot which has not any projection is achieved, and expect that the robot is useful as a rescue robot which can correspond to a variety of use environments.
\end{abstract}

Key words : Spherical monowheel robot, Moving robot, Jumping robot, Stair-climbing, Rescue robot

\section{1. 緒言}

災害時において，崩壊した建造物など人が直接侵入困難な環境下を効率よく移動し，被災情報の収集を行うこ とが可能な移動ロボットが求められている。このようなロボットの特徴として，急斜面や段差，瓦㗂等の存在す る悪路，あるいは狭险空間等における安定した踏破性を有すること，多様な状況に対する耐環境性を備えている こと，可搬性や配備の容易さを考えて十分に小型，軽量であることなどが必要であると考えられている，それら 条件を満たす移動形体として車輪やクローラといった代表的な機構や, 蛇型や魚型等の生体を模倣した機構など 様々な機構が提案されてきたが，近年その一つとして球体形状をした球形ロボットが着目されている. 球形ロボ ットは，従来のロボットの移動機構が持つ方向性を有さないため，落下や転倒等による移動・作業能力の喪失と いった危険性が無いという利点があり，また球形外款でロボット自体が覆われるため，水密性や防塵性などの耐 環境性に優れている．当初球形ロボットは人間共存に適した移動機構として提唱され，その移動，旋回に関する 高い安定性と，障害物や坂道の登攀が可能であることが示された（越山他，1996），(Hlme et al.,1996）。しかしな

\footnotetext{
No.15-00146 [DOI:10.1299/transjsme.15-00146], J-STAGE Advance Publication date : 22 December, 2015

*1 正員，石川工業高等専門学校（干929-0392 石川県河北郡津幡町北中条夕 1)

*2 正員, 金沢大学理工学域 機械工学類 (T920-1192 石川県金沢市角間町)

E-mail of corresponding author: fuji@ishikawa-nct.ac.jp
} 
がら移動原理上，坂道の傾斜角や踏破できる障害物の高さはロボット本体のサイズに比べて小さく，前述のよう な悪路に十分に対応できるものでは無かった。一方，塚越らはこうした球形ロボットが自らの高さより高い障害 物を踏破する手段として，1)連結型，2)投擲牽引型，3）吸着型，4)空中浮遊型（飛行型），5跳躍型の 5 つの形体 を挙げ，このうち俊敏性と狭监空間での移動性から跳躍型を採用し，高い瓦磼踏破性を実現している（塚越他, 2004a). しかしながら, 自律型ではない投擲牵引型を除き, こうした従来の機構, 方法では, 球形ロボットに脚 やばね, 羽根などの機構が付与されるため, 外形に突起物やすきまができ, 完全な球形といえなくなる. その結 果，球形ロボットが持つ無方向性，球形外款による密封性，而環境性といった利点が損なわれるものと考えられ る (佐藤, 2012 など).

以上を背景として, 本研究では, 完全な球形を保った状態で全方向に自律移動と跳躍が可能な球形ロボットの 実現を目的とした，ロボット内部の機械的衝突を利用した跳躍機構を持つ全方向形回転跳踓球形ロボットを提案 する. なお本研究では全方向形回転の定義について, ロボットの内部機構動作の組み合わせにより, ロボット球 形外款が外界に対して前後・旋回および左右方向へ移動が可能であること，とする．各方向への動作原理につい ては 3 章で述べる. 図 1 に本研究における球形ロボットの動作イメージを示す. 本報では実際に同機構を備えた ロボットの設計と開発を行い，その移動・跳躍動作について確認と検証を行った結果について報告する.

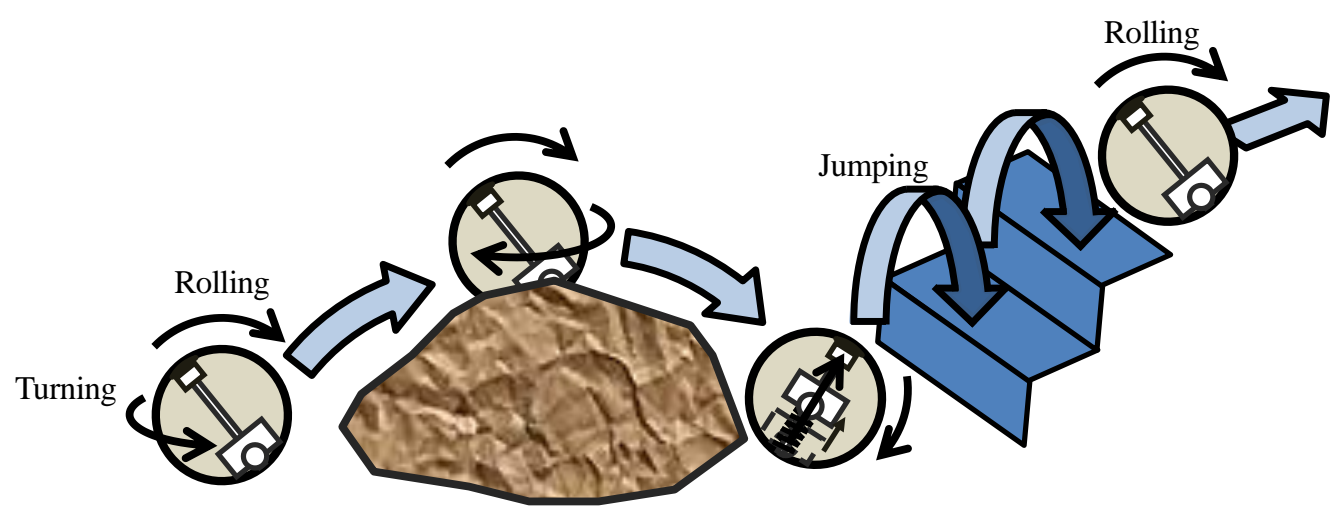

Fig.1 Image of the jumping and rolling of all direction jumping robot

\section{2. 回転跳躍機構}

\section{$2 \cdot 1$ 球形ロボットの跳躍手法}

球形ロボットが障害物の踏破を行う際, 単体で障害物踏破能力を有すること, 悪路や狭险空間における移動の 敏捷性と安定性に優れること，常に外殼が球形を保持できることを要件とし，前述の 5 つの形体のうち跳躍型の 機構について検討した. 球形ロボットが跳躍を行う手段として, 機械的なバネを外部に開放して跳躍する機構

(Ribski et al.,2001), 空気圧シリンダでピストンロッドを外部に打ち出し, その押出し力で跳躍する機構(塚越他, 2004b), 球形外殼の弾性変形による方法 (杉山, 平井，2006）, などが挙げられるが，いずれも球款の外に跳躍機 構を持つため, 球形を保持することは困難であると考えた. ロボット内部の跳躍機能により跳躍を行う方法とし て，ロボットの内部質量の衝突や振動による慣性力を利用した例がある．球形ロボットではないが，菊池らは移 動ロボットの内部質量をばねにより振動させ，その慣性により上下方向の跳躍を行う車輪型ロボットを開発し， 段差の跳躍と着地衝撃の緩和を実現している(菊池他, 2013). またこれと似た跳躍原理を持つ球形ロボットとし て, 中村らが開発した微小重力ローバが挙げられる（中村他, 2001)。これはロボットの内部の鉄球を磁気により 吸引，内壁に衝突させて移動・跳躍を行うものであるが，微小重力下での運用を前提としており，その跳躍量は 垂直方向に $0.013 \mathrm{~m}$ 程の極めて小さいものであった. 以上を踏まえて, 本研究では, 球形ロボットの内部機構を 慣性質量としてばねの弾性により球款上壁に衝突させ，その慣性力によりロボットを跳躍させる跳躍手法とその 機構を新たに提案する. 


\section{$2 \cdot 2$ 回転跳躍機構}

回転跳躍移動体は，(1) 球殼車輪，(3) 球殼車輪内駆動機構，(4) 跳躍機構とそれらをつなぐ(2) 支柱により構 成される. 図 2 にロボットの全体図を，表 1 に主要寸法と外観を，図 3 に本ロボットの跳踓に関連する部分を示 す. 本ロボットは球殼車輪内部を支柱により保持された駆動機構が車輪走行することで球の重心位置が変動し， 球殼車輪の回転トルクとなることで移動を行う。跳躍は圧縮ばねにより駆動機構全体を慣性質量として支柱に沿 って球殼上壁の衝突部へ打ち当て，その衝突慣性によりロボット全体を浮き上がらせる．詳しい運動原理とその モデルは次章に示す。以下，主要な構造と機構について述べる.

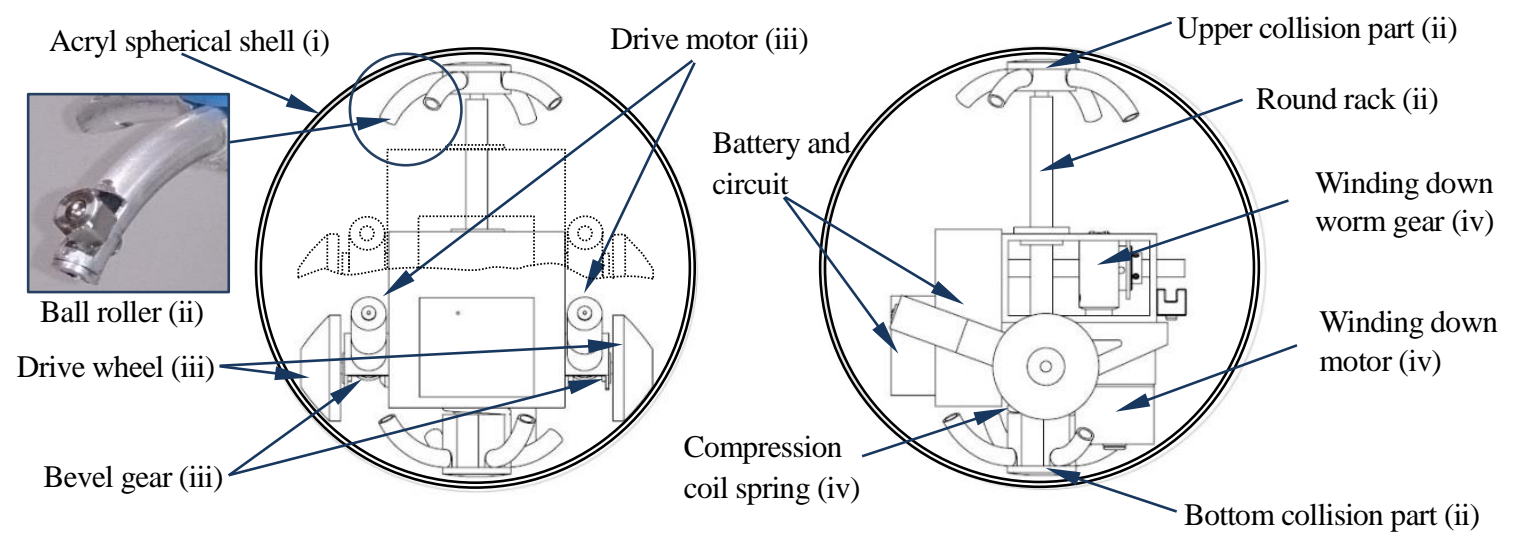

Fig. 2 Constitution of the rolling and jumping movement robot

Table 1 Outward form of rolling and jumping movement robot and main dimension

\begin{tabular}{|l|l|c|r}
\hline \hline & \multicolumn{1}{|c|}{ Specification items } & Symbols & \multicolumn{1}{c}{ Values } \\
\cline { 2 - 4 } & Diameter of spherical shell & $D$ & $0.2 \mathrm{~m}$ \\
\hline & Total weight & $M$ & $1.5146 \mathrm{~kg}$ \\
\hline & Weight of spherical shell & $M_{1}$ & $0.4 \mathrm{~kg}$ \\
\cline { 2 - 4 } & Weight of internal mechanism & $M_{2}$ & $1.1146 \mathrm{~kg}$ \\
\cline { 2 - 4 } & Maximum height of jumping & $z_{\max }$ & $0.43 \mathrm{~m}$ \\
\hline & Spring constant & $k$ & $9810 \mathrm{~N} / \mathrm{m}$ \\
\cline { 2 - 4 } & Compression displacement amount & $x_{0}$ & $0.056 \mathrm{~m}$ \\
\hline
\end{tabular}

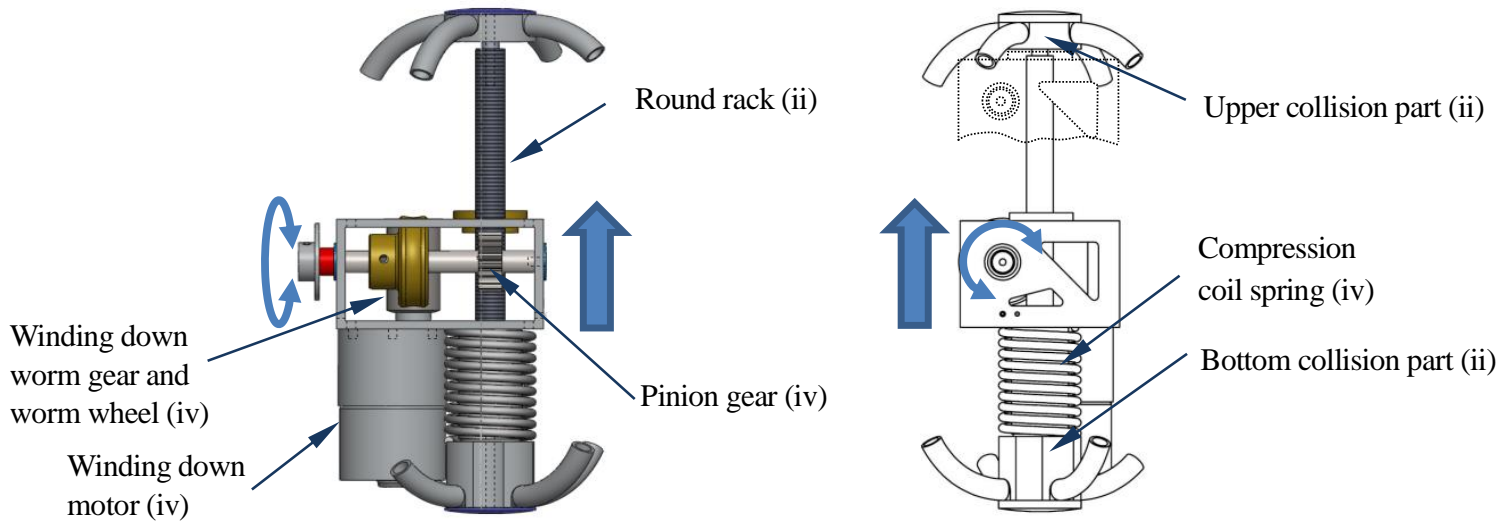

Fig. 3 Mechanism for jumping of the rolling and jumping movement robot 
(i ) 球殼車輪 : 球殼車輪は外径 $0.2 \mathrm{~m}$, 内径 $0.195 \mathrm{~m}$ のアクリル半球により構成される. 球殼車輪はロボット本 体の車輪としての役割をもち，また球形の維持，密閉性や防塵性を保持する要素として機能する.

(ii) 支柱 : 支柱は球殼車輪内で駆動機構を保持し, さらに跳踓時には駆動機構全体を打ち上げる案内軸として 作用する．その上下端は球殼内壁にボールローラ（MISUMI：BCHL5）を介して接触しており，回転移動時に内 部駆動機構が球殼内壁から乘離することを防ぐ，ボールローラは図 2 に示寸ように，支柱上下端部から内壁に沿 って四方に這わせた丸管の先端に内壁と接するように上下それぞれ 4 づつ取り付けられ，駆動機構の球殼内で の回転を補助する. また駆動機構の巻き下げと保持のため, 支柱には丸ラック（KHK：SRO1-500）を使用する.

（iii）駆動機構：球殼車輪内壁に接する樹脂製の駆動車輪を駆動させることで，球殼車輪の回転方向，速度を制 御する. 駆動車輪のホイールは MCナイロン製で, さらに滑り防止と緩衝のため接触面に厚さ $0.01 \mathrm{~m}$ のウレタン 樹脂が張り付けられている．移動時における内部構造の重心は球殼車輪の外壁側に近いほど移動が安定し，同時 にばねの圧縮量も増えることから跳躍量も増加するため, 移動状態での駆動機構は球殼中心より外殼よりに配置 する.

(iv) 跳躍機構 : 跳躍のための巻き下げ機構と圧縮ばね（Sotec：IVO31-100）を，支柱を案内軸として駆動機構 の内部に配置する．支柱の下端と駆動機構の底面との間に圧縮ばねを挟み，これを支柱に沿って下限まで巻き下 げる．巻き下げた状態が本ロボットの回転移動形態となる（図 2)。この状態からばねを開放することで，駆動機 構と巻き下げ機構自体が支柱に沿って打ち上げられ，球凯車輪内壁上部へ衝突し，その慣性によりロボットの跳 躍を行う．巻き下げを行うピニオン（KHK：SSA1-20）の歯を4つ削り，欠け歯車とすることで，ピニオンの回 転数により巻き下げ量と開放タイミングを制御する. 開放時，内部機構は球殼車輪内壁との接触状態からさらに 最大 2 ピッチ $\left(2 \pi \times 10^{-3} \mathrm{~m}\right)$ 巻き下げられるが，その変形の大部分は駆動車輪のウレタン樹脂部で吸収される. 実験でも開放機構の巻き下げによる球殼車輪の大きな変形や回転・跳躍動作への影響は見られなかった．なお， 跳躍時には駆動車輪が球殼内壁から離れるため, 跳躍の間は球殼車輪へ駆動動力は伝わらない.

\section{3. 動作原理}

\section{$3 \cdot 1$ 直進走行の原理とモデル}

完全球形ロボットにおける直進走行および旋回動作は，球殼内駆動機構に配置した 2 個の駆動車輪を制御する ことで行われる. 図 4 に直進走行時の進行方向対して真横から見たモデルを, 表 2 にモデルパラメータを示す. 完全球形ロボットにおいて内部の駆動機構が支柱によりその位置を保持されているとき, 球殼車輪の回転中心と 駆動機構の重心の位置との距離は常に一定の值となる. 駆動機構が図のように球款車輪内を駆け上がることで, 球殼車輪内での駆動機構の重心位置が変化し, 球殼車輪の接地点に対するピッチ方向への回転トルクが発生して, ロボットの直進走行が実現される．またこのとき，直進走行の運動方程式は球凯車輪の回転運動と球殼車輪に対 する駆動機構の回転運動についてそれぞれ式(1)，(2)のように求まる. 摩擦トルク $T_{f x 1}$ および $T_{f x 2}$ として，車輪の 角速度 $\dot{\theta}_{x 1}$ および $\dot{\theta}_{x 2}$ の絶対值が十分に小さく回転していないとみなせる場合, 静摩擦トルク $T_{f x 1-s}, T_{f x 2-s}$ を用い, それより大きい場合はクーロン摩擦トルク $T_{f x l-c}, T_{f x 2-c}$ を用いた．またクーロン摩擦トルクの符号は角速度の正負 により定まる．闇值は越山らに倣い，計算上無視できる值として $10^{-8} \mathrm{rad} / \mathrm{s}$ を用いた（越山他，1996）.

$$
\begin{aligned}
& \left\{J_{G x 1}+J_{G x 2}+M_{1} r_{1}^{2}+M_{2} r_{1}^{2}+M_{2} e_{2}^{2}+2 M_{2} r_{1} e_{2} \sin \left(\theta_{x 1}+\theta_{x 2}\right)\right\} \ddot{\theta}_{x 1} \\
& +\left\{J_{G x 2}+M_{2} e_{2}^{2}+M_{2} r_{1} e_{2} \sin \left(\theta_{x 1}+\theta_{x 2}\right)\right\} \ddot{\theta}_{x 2}+M_{2} r_{1} e_{2} \cos \left(\theta_{x 1}+\theta_{x 2}\right) \dot{\theta}_{x 1}^{2} \\
& +M_{2} r_{1} e_{2} \cos \left(\theta_{x 1}+\theta_{x 2}\right) \dot{\theta}_{x 2}^{2}+2 M_{2} r_{1} e_{2} \cos \left(\theta_{x 1}+\theta_{x 2}\right) \dot{\theta}_{x 1} \dot{\theta}_{x 2} \\
& +D_{\theta x 1} \dot{\theta}_{x 1}+M_{2} g e_{2} \cos \left(\theta_{x 1}+\theta_{x 2}\right)+T_{f x 1}=T_{x 1} \\
& \left\{J_{G x 2}+M_{2} e_{2}^{2}+M_{2} r_{1} e_{2} \sin \left(\theta_{x 1}+\theta_{x 2}\right)\right\} \ddot{\theta}_{x 1}+\left(J_{G x 2}+M_{2} e_{2}^{2}\right) \ddot{\theta}_{x 2} \\
& +D_{\theta x 2} \dot{\theta}_{x 2}+M_{2} g e_{2} \cos \left(\theta_{x 1}+\theta_{x 2}\right)+T_{f x 2}=T_{x 2}
\end{aligned}
$$




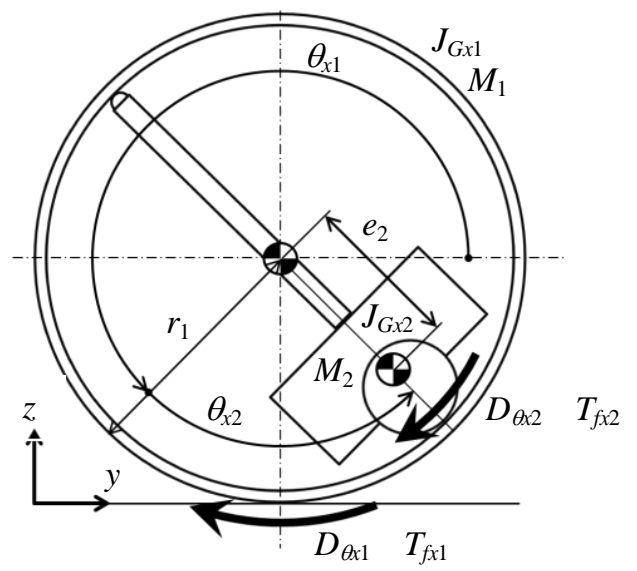

Fig. 4 Modeling of straight running

Table 2 Model parameters for straight running

\begin{tabular}{c|l|r}
\hline \hline Symbol & \multicolumn{1}{|c|}{ Parameters } & Values \\
\hline$r_{1}$ & Radius of spherical shell & $0.1 \mathrm{~m}$ \\
\hline$e_{2}$ & Distance between the centroids of the internal mechanism and the spherical shell & $0.02273 \mathrm{~m}$ \\
\hline$\theta_{x 1}$ & Rotation Angle of the spherical shell from the ground & - \\
\hline$\theta_{x 2}$ & Rotation Angle of the internal mechanism from the spherical shell (Initial value $:-5 / 2 \pi)$ & - \\
\hline$J_{\mathrm{Gx} 1}$ & Moment of inertia of the centroid of the spherical shell & $0.002601 \mathrm{kgm}^{2}$ \\
\hline$J_{\mathrm{Gx} 2}$ & Moment of inertia of the centroid of the internal mechanism & $0.00262 \mathrm{kgm}^{2}$ \\
\hline$M_{1}$ & Mass of the spherical shell & $0.4 \mathrm{~kg}$ \\
\hline$M_{2}$ & Mass of the internal mechanism & $1.1146 \mathrm{~kg}$ \\
\hline$D_{\theta x 1}$ & Viscous friction torque coefficient between the spherical shell and the ground & $0.001 \mathrm{Nms}$ \\
\hline$D_{\theta x 2}$ & Viscous friction torque coefficient between the spherical shell and the internal mechanism & $0.245 \mathrm{Nms}$ \\
\hline & Coulomb friction torque and static friction torque between the spherical shell and the ground. & $T_{f x 1-c}: 0.0001 \mathrm{Nm}$ \\
$T_{f x 1}$ & $T_{f x 1}=T_{f x 1-s}\left(\left|\dot{\theta}_{x 1}\right| \leq 10^{-8} \mathrm{rad} / \mathrm{s}\right), T_{f x 1}=T_{f x 1-c}\left(\dot{\theta}_{x 1}>10^{-8} \mathrm{rad} / \mathrm{s}\right), T_{f x 1}=-T_{f x 1-c}\left(\dot{\theta}_{x 1}<-10^{-8} \mathrm{rad} / \mathrm{s}\right)$ & $T_{f x 1-s}: 0.1 \mathrm{Nm}$ \\
\hline & Coulomb friction torque and static friction torque between the spherical shell and the internal & $T_{f x 2-c}: 0.06 \mathrm{Nm}$ \\
\hline$T_{f x 2}$ & mechanism & $T_{f x 2-s}: 0.1 \mathrm{Nm}$ \\
\hline$T_{x 1}$ & $T_{f x 2}=T_{f x 2-s}\left(\left|\dot{\theta}_{x 2}\right| \leq 10^{-8} \mathrm{rad} / \mathrm{s}\right), T_{f x 2}=T_{f x 2-c}\left(\dot{\theta}_{x 2}>10^{-8} \mathrm{rad} / \mathrm{s}\right), T_{f x 2}=-T_{f x 2-c}\left(\dot{\theta}_{x 2}<-10^{-8} \mathrm{rad} / \mathrm{s}\right)$ & - \\
\hline$T_{x 2}$ & Driving torque of the spherical shell & Input torque to driving wheel \\
\hline
\end{tabular}

\section{$3 \cdot 2$ 旋回動作の原理とモデル}

図 5 に旋回動作時のロボットを旋回軸方向から見たモデルを示す。また表 3 にそのモデルパラメータを示す. 本ロボットは内部機構の駆動車輪を逆方向に同一角度駆動させることにより旋回半径 0 の旋回走行を行う。この ときの反作用により球殼車輪が内部駆動機構とは逆向きに一 $\theta_{z 1}$ 回転するが，地面と球凯車輪との摩擦が 0 でない かぎり， $\theta_{z 1}<\theta_{z 2}$ となる．旋回動作における運動方程式は，球殼車輪の回転運動と球殼車輪に対寸る駆動機構の回 転運動についてそれぞれ式(3), (4)のように求まる. また前節同様, 摩擦トルク $T_{f z 1}$ および $T_{f 22}$ は, 角速度 $\dot{\theta}_{z 1}$ およ び $\dot{\theta}_{z 2}$ の絶対值が， $10^{-8} \mathrm{rad} / \mathrm{s}$ を閾值として，これより小さいときは静摩擦トルクを，大きい場合はクーロン摩擦 を用いた，正負についても同様である.

$$
\begin{aligned}
& \left(J_{G z 1}+J_{G z 2}\right) \ddot{\theta}_{z 1}+J_{G z 2} \ddot{\theta}_{z 2}+D_{\theta z 1} \dot{\theta}_{z 1}+T_{f z 1}=T_{z 1} \\
& J_{G z 2} \ddot{\theta}_{z 1}+J_{G z 2} \ddot{\theta}_{z 2}+D_{\theta z 2} \dot{\theta}_{z 2}+T_{f z 2}=T_{z 2}
\end{aligned}
$$




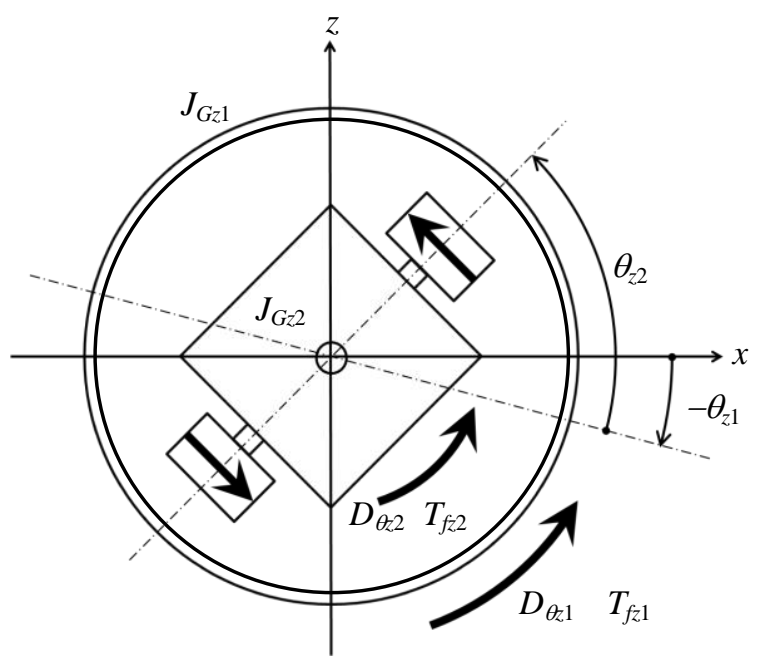

Fig. 5 Modeling of pivot turn

Table 3 Model parameters for movement of pivot turn

\begin{tabular}{c|l|r}
\hline \hline Symbol & \multicolumn{1}{c}{ Parameters } & Values \\
\hline$\theta_{z 1}$ & Rotation Angle of the spherical shell from the ground & - \\
\hline$\theta_{z 2}$ & Rotation Angle of the internal mechanism from the spherical shell & - \\
\hline$J_{\mathrm{G} z 1}$ & Moment of inertia of the centroid of the spherical shell & $0.002601 \mathrm{kgm}^{2}$ \\
\hline$J_{\mathrm{G} z 2}$ & Moment of inertia of the centroid of the internal mechanism & $0.00184 \mathrm{kgm}{ }^{2}$ \\
\hline$D_{\theta z 1}$ & Viscous friction torque coefficient between the spherical shell and the ground & $0.001 \mathrm{Nms}$ \\
\hline$D_{\theta z 2}$ & Viscous friction torque coefficient between the spherical shell and the internal mechanism & $0.265 \mathrm{Nms}$ \\
\hline & Coulomb friction torque and static friction torque between the spherical shell and the ground & $T_{f z 1-c}: 0.1 \mathrm{Nm}$ \\
$T_{f z 1}$ & $T_{f z 1}=T_{f x 1-s}\left(\left|\dot{\theta}_{z 1}\right| \leq 10^{-8} \mathrm{rad} / \mathrm{s}\right), T_{f z 1}=T_{f z 1-c}\left(\dot{\theta}_{z 1}>10^{-8} \mathrm{rad} / \mathrm{s}\right), T_{f z 1}=-T_{f z 1-c}\left(\dot{\theta}_{z 1}<-10^{-8} \mathrm{rad} / \mathrm{s}\right)$ & $T_{f z 1-s}: 0.1 \mathrm{Nm}$ \\
\hline & $\begin{array}{l}\text { Coulomb friction torque and static friction torque between the spherical shell and the internal } \\
\text { mechanism }\end{array}$ & $T_{f z 2-c}: 0.06 \mathrm{Nm}$ \\
$T_{f z 2}$ & $T_{f z 2}=T_{f z 2-s}\left(\left|\dot{\theta}_{z 2}\right| \leq 10^{-8} \mathrm{rad} / \mathrm{s}\right), T_{f z 2}=T_{f z 2-c}\left(\dot{\theta}_{z 2}>10^{-8} \mathrm{rad} / \mathrm{s}\right), T_{f z 2}=-T_{f z 2-c}\left(\dot{\theta}_{z 2}<-10^{-8} \mathrm{rad} / \mathrm{s}\right)$ & \\
\hline$T_{z 1}$ & Driving torque of the spherical shell & - \\
\hline$T_{z 2}$ & Input torque to driving wheel & - \\
\hline
\end{tabular}

\section{$3 \cdot 3$ 跳躍動作の原理とモデル}

跳躍動作のロボットを側面から見たモデルを図 6 に，モデル化変数を表 4 に示す．支柱部を除く内部機構が圧 縮ばねを挟んで球殼車輪の内壁側（図下方）に押し付けられた状態からばねが開放されることで，ばねの弾性エ ネルギーが内部機構の位置・運動エネルギーに変化し, 支柱上端衝突部に衝突する. 衝突が非弾性である場合, 内部機構を含めた球体全体がバネの解放方向に跳躍運動を行う。ばねが自由長のとき上端と衝突するため, 衝突 が完全非弾性でかつスライド時の摩擦が無いと仮定したとき跳躍初期速度と跳躍高さは式（5)，（6）となり，ま た最大跳躍量は式 (7) となる. 実際の衝突は反発係数があり, 打ち上げ時に支柱丸ラックとスライドブシュ間の 摩擦損失があるため跳躍量はこれより小さな値となると考えられる.

$$
\begin{aligned}
& v_{2}=\frac{m_{2}}{m_{1}+m_{2}} v_{1}=\frac{m_{2}}{m_{1}+m_{2}} \sqrt{\frac{k}{m_{2}} x_{0}^{2}} \\
& z(t)=\left(\frac{m_{2}}{m_{1}+m_{2}} \sqrt{\frac{k}{m_{2}} x_{0}^{2}}\right) t-\frac{1}{2} g t^{2}
\end{aligned}
$$




$$
z_{\max }=\frac{m_{2}}{\left(m_{1}+m_{2}\right)^{2}}\left(\frac{k x_{0}^{2}}{2 g}\right)=0.7668 \mathrm{~m}
$$

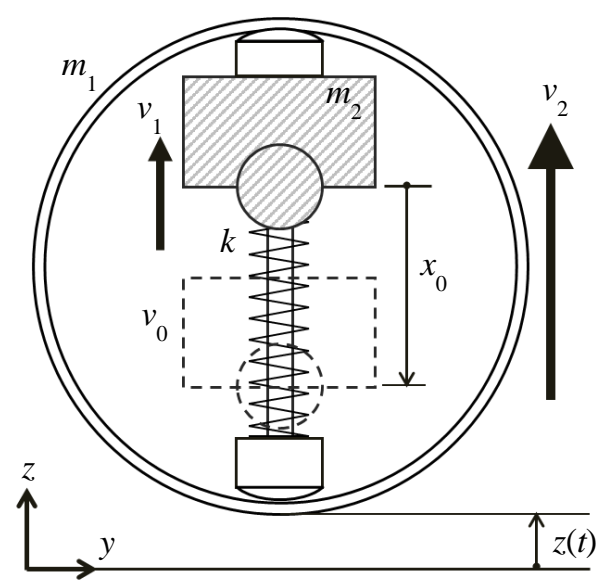

Fig. 6 Modeling of vertical jumping

Table 4 Model parameters for the movement of vertical jumping

\begin{tabular}{c|l|r}
\hline \hline Symbol & \multicolumn{1}{|c}{ Parameters } & \multicolumn{1}{c}{ Values } \\
\hline$x_{0}$ & Initial deflection of the coil spring from the equilibrium position & $0.056 \mathrm{~m}$ \\
\hline$m_{1}$ & Mass of the spherical shell and the supporting column & $0.4 \mathrm{~kg}$ \\
\hline$m_{2}$ & Mass of the internal mechanism without the supporting column & $1.1 \mathrm{~kg}$ \\
\hline$z_{\max }$ & Maximum height of jumping (theoretical value) & $0.7668 \mathrm{~m}$ \\
\hline$g$ & Gravity acceleration & $9.80665 \mathrm{~m} / \mathrm{s}^{2}$ \\
\hline$k$ & Spring constant & $9810 \mathrm{~N} / \mathrm{m}$ \\
\hline$v_{1}$ & Velocity the internal mechanism (without the supporting column) in collision & - \\
\hline$v_{2}$ & Initial velocity of the jumping & - \\
\hline
\end{tabular}

\section{$3 \cdot 4$ 斜方跳躍の跳躍過程とモデル}

障害物の乗り越えや階段の上昇などを想定した本ロボットの斜方跳躍過程について図 7 に, 斜方跳躍中のロボ ットの重心の位置および速度を式（8），（9）に示す．また斜方跳躍に関するモデル化変数を表 5 に示す．このう ち $D_{\theta x 1 j}$ は空気の粘度 $\left(1.8 \times 10^{-5} \mathrm{~Pa} \cdot \mathrm{s}\right)$ および球殼車輪寸法から計算した值を用いた. $D_{\theta x 2 j}$ については, 理想的な 状態として跳躍中の内部機構と内壁との接触力はほぼないと仮定し, 計算上影響のない程度に小さい值を用いた. $T_{f x 1 j}, T_{f x 2 j}$ についても接触力が微小であると仮定して同様に計算上十分に小さな值を用いた. 值の桁数については 次元を考慮した. 式 (8), （9）より本ロボットの跳躍量は打ち出される際の跳躍角度により定まる. 跳躍角度の 制御は直進走行動作において生じる内部機構の傾斜を利用して実現する。まず跳躍開始位置まで直進走行を行い 移動する (図 7 (a)). 次に正の回転慣性を保った状態で進行方向に対し内部機構を逆回転する（図 7 (b)). 内部機 構の傾斜が跳躍角度に合致したタイミングでピニオンを回し，圧縮ばねを開放することで目的の方向に衝突が起 こり跳躍する (図 7 (c)).

次に跳躍角度と跳躍方向の調整方法について説明する. 図 8 に直進走行モデルに基づく斜方跳躍打ち出しまで の回転角度とその際の内部機構姿勢を示す．0 0.4s 間は停止状態，0.4 0.6s 間は直進，0.6〜 $1.0 \mathrm{~s}$ 間は内部機構の 逆回転区間，1.0 1.5s は斜方跳躍区間である. 入力トルク $T_{x 2}$ は，0.4 0.6s 間で $0.245 \mathrm{Nm} ， 0.6 \sim 0.7 \mathrm{~s}$ 間の停止区間 をはさみ，0.7 1.0s 間に-0.245 Nm の定トルク入力を与えた. 最初の直進走行により球款車輪が正回転の慣性を有 した状態で内部機構に負回転のトルクが加わることで，ロボットが後退することなく内部機構のみ前方一傾き跳

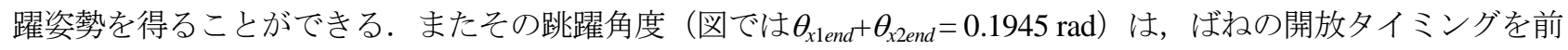


後することで容易に調整することが可能である．なお跳躍による移動方向に関しては，内部機構の旋回動作によ るロボットの進行方向が移動方向となる.

なお，跳躍中は球殼車輪と内部の駆動車輪は接触していないため，跳躍時の回転状態と内部機構の重心位置に より球体ロボット重心を中心とした回転運動を行う。跳躍時の状態を側面から見たモデルを図 9 に，跳躍中の回 転運動状態を式（10），(11）に示す.

$$
\begin{aligned}
& \left\{\begin{array}{l}
y(t)=v_{2} t \cos \left(\theta_{x 1 \text { end }}+\theta_{x 2 \text { end }}\right)+r_{1} t\left(\dot{\theta}_{x 1 \text { end }}+\dot{\theta}_{x 2 \text { end }}\right)+y_{0} \\
z(t)=v_{2} t \sin \left(\theta_{x 1 \text { end }}+\theta_{x 2 \text { end }}\right)-\frac{1}{2} g t^{2}+z_{0}
\end{array}\right. \\
& \left\{\dot{y}(t)=v_{2} \cos \left(\theta_{x 1 \text { end }}+\theta_{x 2 e n d}\right)+r_{1}\left(\dot{\theta}_{x 1 \text { end }}+\dot{\theta}_{x 2 \text { end }}\right)\right. \\
& \dot{z}(t)=v_{2} \sin \left(\theta_{x 1 \text { end }}+\theta_{x 2 \text { end }}\right)-g t \\
& \left(J_{G x 2 j}+M_{1} a^{2}+M_{2} b^{2}\right) \ddot{\theta}_{x 1 j}+\left(J_{G x 2 j}+M_{1} a^{2}+M_{2} b^{2}\right) \ddot{\theta}_{x 2 j}+D_{\theta x 2 j} \dot{\theta}_{x 2 j}+T_{f x 2}=T_{x 1 j} \\
& \left(J_{G x 1}+J_{G x 2 j}+M_{1} a^{2}+M_{2} b^{2}\right) \ddot{\theta}_{x 1 j}+\left(J_{G x 2 j}+M_{1} a^{2}+M_{2} b^{2}\right) \ddot{\theta}_{x 2 j}+D_{\theta x 1 j} \dot{\theta}_{x 1 j}=T_{x 1 j}
\end{aligned}
$$

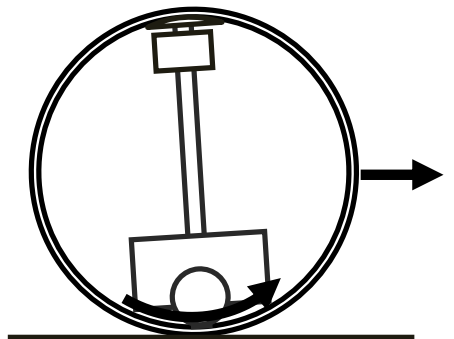

(a) Rolling to position at jumping

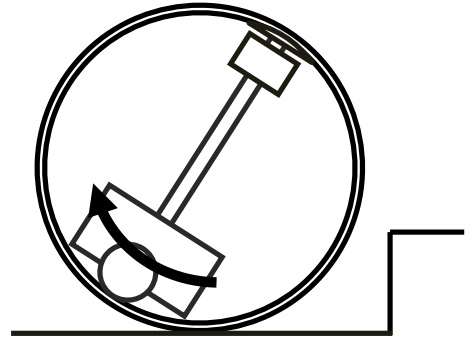

(b) Posture adjustment for jumping

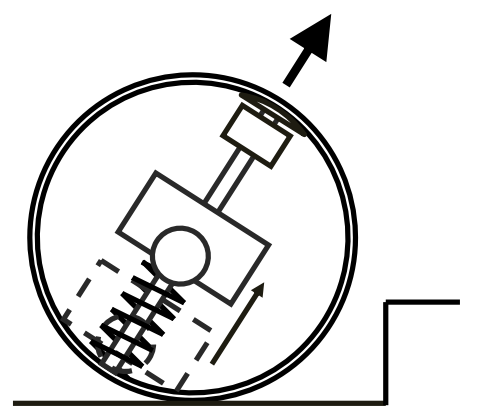

(c) Jumping movement

Fig. 7 Procedure of jumping over obstacles

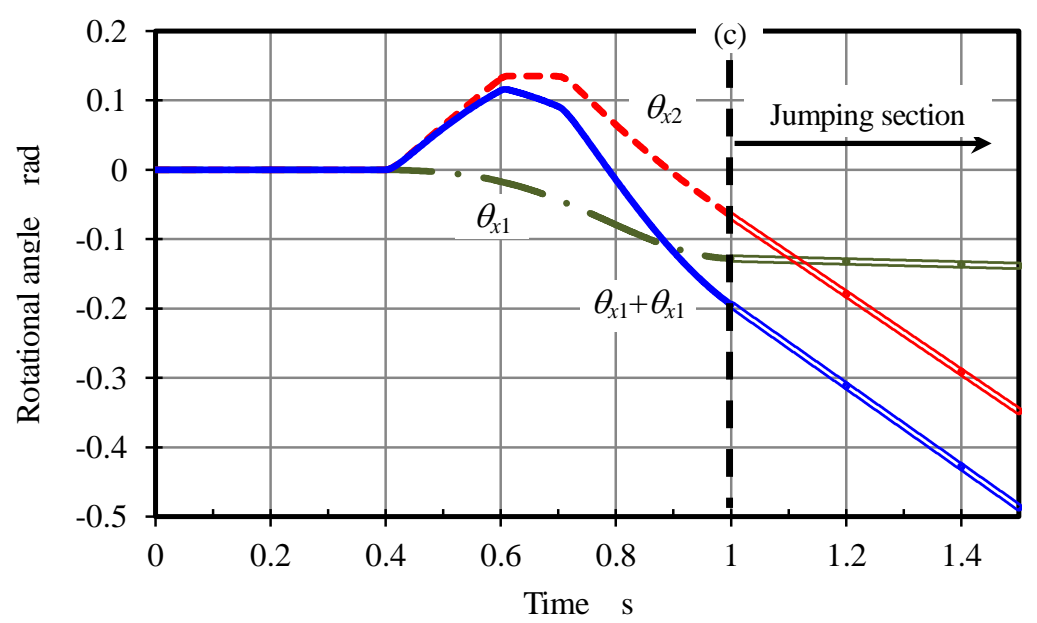

Fig. 8 Rotational angle of procedure of jumping over obstacles. Rotation Angle of the internal mechanism from the spherical shell is plotted with solid line (blue). Rotation Angle of the spherical shell from the ground is plotted with dotted line (red). Rotation Angle of the internal mechanism from the ground is plotted with dashed line (green). Orbits of their angle during the jump are plotted with double line respectively. 


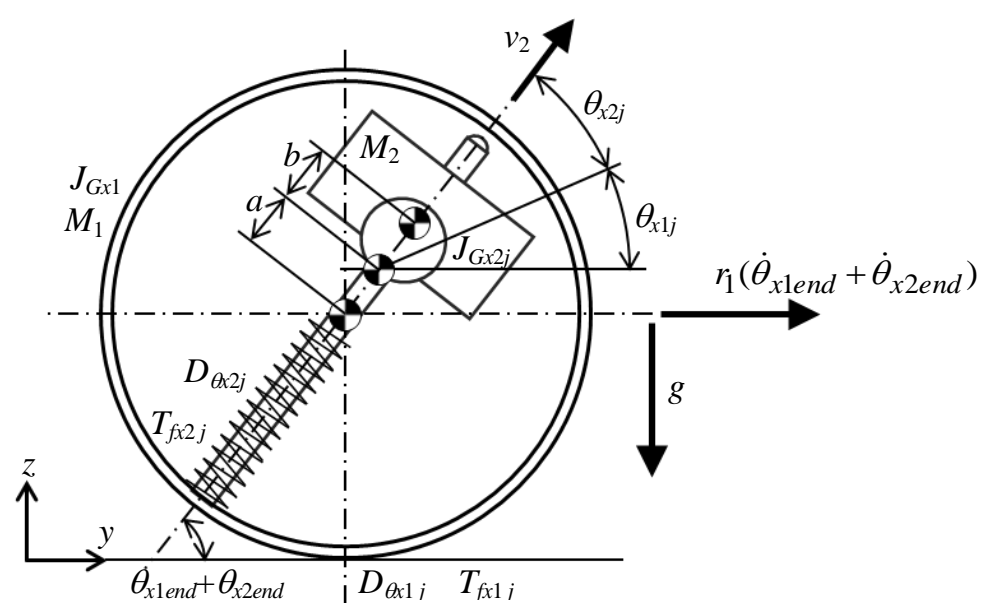

Fig. 9 Modeling of jumping over obstacles

Table 5 Model parameters for jumping over obstacles

\begin{tabular}{|c|c|c|}
\hline Symbol & Parameters & Values \\
\hline$y_{0}$ & Initial position in y axis direction & - \\
\hline$z_{0}$ & Initial position in $\mathrm{z}$ axis direction & - \\
\hline$\theta_{x 1 \text { end }}$ & Rotation Angle of $\theta_{x 1}$ at the occurrence jumping & - \\
\hline$\theta_{x 2 e n d}$ & Rotation Angle of $\theta_{x 2}$ at the occurrence jumping & - \\
\hline$v_{2}$ & Initial velocity of the jumping & - \\
\hline$\theta_{x 1 j}$ & Rotation Angle of the spherical shell from the ground in jumping & - \\
\hline$\theta_{x 2 j}$ & Rotation Angle of the internal mechanism from the spherical shell in jumping & - \\
\hline$D_{\theta x 1 j}$ & Viscous friction torque coefficient between the spherical shell and the air in jumping & $2.2619 \times 10^{-7} \mathrm{Nms}$ \\
\hline$D_{\theta x 2 j}$ & $\begin{array}{l}\text { Viscous friction torque coefficient between the spherical shell and the internal mechanism in } \\
\text { jumping }\end{array}$ & $10^{-9} \mathrm{Nms}$ \\
\hline$T_{f x 1 j}$ & $\begin{array}{l}\text { Coulomb friction torque and static friction torque between the spherical shell and the air in } \\
\text { jumping }\end{array}$ & $\begin{array}{c}T_{f x 1 j-c:}: 10^{-6} \mathrm{Nm} \\
T_{f x 1 j-s}: 0 \mathrm{Nm}\end{array}$ \\
\hline$T_{f x 2 j}$ & $\begin{array}{l}\text { Coulomb friction torque and static friction torque between the spherical shell and the internal } \\
\text { mechanism in jumping }\end{array}$ & $\begin{array}{l}T_{f x 2 j-c}: 10^{-6} \mathrm{Nm} \\
T_{f x 2 j-s}: 0 \mathrm{Nm}\end{array}$ \\
\hline$T_{x 1 j}$ & Rotational torque of the spherical shell in jumping & $0 \mathrm{Nm}$ \\
\hline$T_{x 2 j}$ & Rotational torque of the internal mechanism in jumping & $0 \mathrm{Nm}$ \\
\hline$a$ & Distance between the centroids of the robot and the spherical shell in jumping & $0.0227 \mathrm{~m}$ \\
\hline$b$ & Distance between the centroids of the robot and the internal mechanism in jumping & $0.0082 \mathrm{~m}$ \\
\hline$\theta_{\text {end }}$ & Posture angle of the robot at the occurrence jumping $\left(=\theta_{x 1 e n d}+\theta_{x 2 e n d}\right)$ & - \\
\hline$\omega_{\text {end }}$ & Angular velocity of the robot at the occurrence jumping & - \\
\hline
\end{tabular}

\section{4. 実験}

\section{$4 \cdot 1$ 移動および旋回動作}

移動および旋回機能の検証のため，平面上での直進走行および旋回実験を行った.

直進走行は移動体を弾性ウレタン樹脂系の塗り床材の床に設置し, 左右の駆動車輪を同方向に同一角度回転さ せ行った．駆動車輪への指令值は停止状態から等速走行を経て，駆動機構が球殼車輪に対して $4 \mathrm{rad}$ 回転した後 に停止するよう式（12）の制御則に従い指令トルクを与えた. システムパラメータを表 6 に示す（オーバーシュ 一ト量 20\%の CHR 法により定めた). 駆動機構の傾斜角は内部制御基板上の 3 軸加速度センサから, 球殻車輪の 実回転角度は球殼車輪のマーカーの座標を撮影画像から $0.2 \mathrm{~s}$ 間隔で計測して求めた. 図 10 に直進走行結果を示 す．実線は式 (1)，（2）による計算機シミュレーション結果を，プロットは実動作を示す．球殼車輪の回転角度 はおよそ周期 $2 \mathrm{~s}$ の振動を伴いつつ, 内部駆動機構の回転と反対方向に回転しながら前進した. 計算結果と実機 の動作はほぼ一致しており，跳躍機構を内蔵した本ロボットにおいて直進動作を実現することができた。 
旋回動作は，直進走行と同様の床面で，左右の駆動車輪を逆方向に同一角度回転させ行った．駆動車輪への指 令值は停止状態から駆動機構が球殼車輪に対して $0.98 \mathrm{rad}$ 旋回した後に停止するよう, 同様の制御則で位置サー ボ入力を加えることで行った．パラメータを表 6 に付記する. 内部機構の角度および球殼車輪の旋回量の計測方 法も同様である. 図 11 に旋回動作結果を示す. 実線は式 (3), (4) による計算機シミュレーション結果を, プロ ットは実動作を示す．床面および駆動車輪の摩擦係数が高いため球殼車輪の反転がほとんど見られず，駆動車輪 による回転がほぼそのままロボットの旋回角度となっている。これは摩擦卜ルクが支配的な場合の球形ロボット の旋回特性であり, 計算結果ともよく一致している. 以上の結果から本ロボットにおいて球殼車輪内部で駆動車 輪を回転することで内部機構は地面に対して旋回できることが示され，これにより本ロボットが旋回原理に基づ き半径 0 の旋回を行うことができた.

以上の動作は越山や Halme らの球形ロボットにおける直進走行や旋回動作結果とも合致しており，これより本 ロボットが従来の球形ロボットの動作原理に基づいた平地での走行機能を実現していることが実験的に示された.

$$
T_{x 2}=K_{x 2-p}\left(\theta_{x 2 r}-\theta_{x 2}\right)+K_{x 2-i} \sum\left(\theta_{x 2 r}-\theta_{x 2}\right)+K_{x 2-d}\left(\dot{\theta}_{x 2 r}-\dot{\theta}_{x 2}\right)
$$

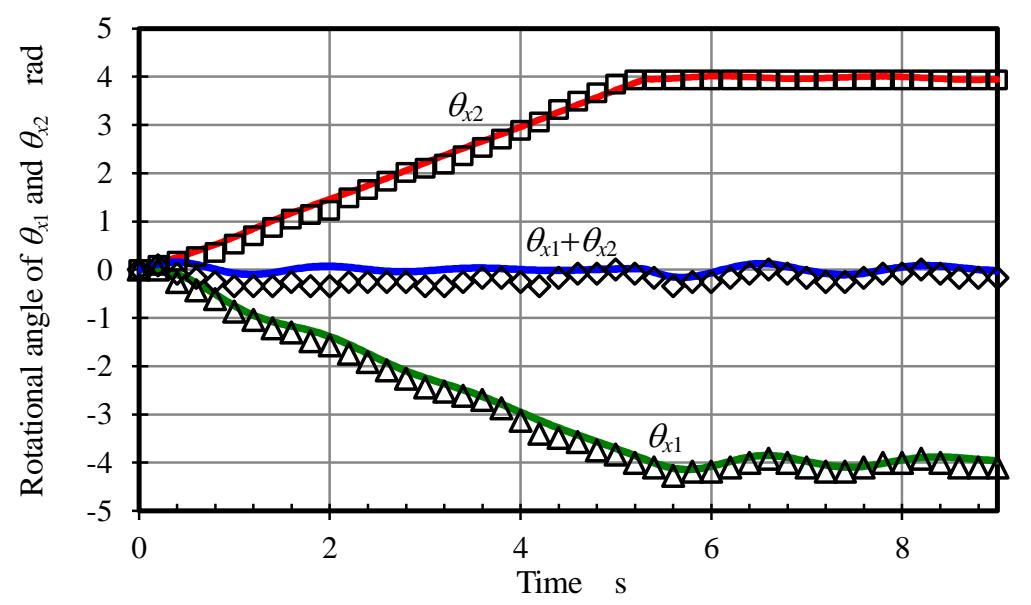

Fig. 10 Result of straight running. Experimental rotational angle of $\theta_{x 1}, \theta_{x 2}$ and their additional value are plotted with square dots, diamond dots and triangle dots respectively. Each theoretical values are plotted with the solid line (red blue green) respectively.

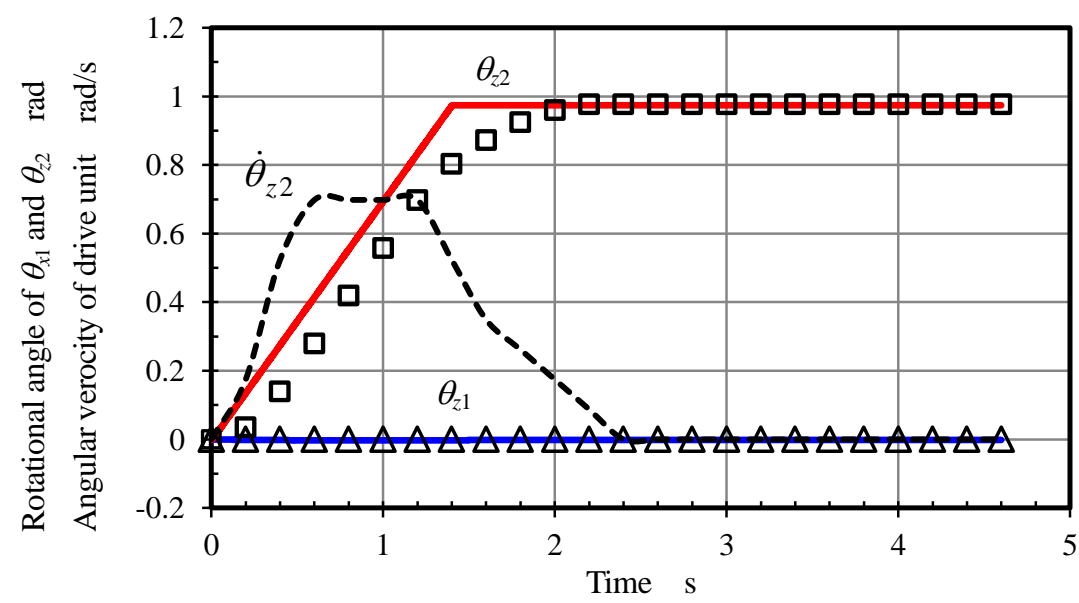

Fig. 11 Result of pivot turn. Experimental rotational angle of $\theta_{x 1}, \theta_{x 2}$ are plotted with square dots and triangle dots respectively. Each theoretical values are plotted with the solid line (red blue green). Angular velocity of $\theta_{x 2}$ is plotted with dotted line. 
Fujioka, Nakamura and Seki, Transactions of the JSME (in Japanese), Vol.82, No.833 (2016)

Table 6 System parameters for PID control for straight running

\begin{tabular}{l|c|r|r|r}
\hline \hline \multicolumn{1}{c|}{ Parameters } & Symbol & $\begin{array}{c}\text { Values of } \\
\text { straight running }\end{array}$ & Symbol & $\begin{array}{c}\text { Values of } \\
\text { pivot turn) }\end{array}$ \\
\hline Proportional gain around x axis & $K_{x 2-p}$ & 17.0880 & $K_{z 2-p}$ & 11.3218 \\
\hline Integration gain around x axis & $K_{x 2-i}$ & 0.0324 & $K_{z 2-i}$ & 0.0427 \\
\hline Variable gain around x axis & $K_{x 2-d}$ & 0.0001 & $K_{z 2-d}$ & 0.0001 \\
\hline
\end{tabular}

\section{$4 \cdot 2$ 跳躍動作}

ロボットの跳躍機能の確認と検証を行うため，同床面上で内部の駆動機構を静止した状態から跳躍機構のみを 作動させ，静止状態からの鉛直方向跳躍を行った．実機の跳躍量は鉛直跳躍時の挙動をカメラで撮影し，球殼車 輪の中心座標を記録した．跳躍時の実際の様子を図 12 に，図 13 に式（6）に基づく跳躍軌道の計算值とその実験 值を示す. 図では静止状態の球殼車輪中心をグラフ原点とした. 式 (7) より, 内部機構の衝突が完全非弾性衝突 で，かつ打ち上げ時の摩擦損失が 0 と仮定した場合の最大跳躍量は $z_{\max }=0.7668 \mathrm{~m}$ となるが，今回，実機による平 均跳躍高さは $0.43 \mathrm{~m}$ （標準偏差 $s_{n}=0.0095 \mathrm{~m} ）$ となり, 計算值の $56 \%$ 程度に留まった. 本ロボットにおける跳躍高 さが損なわれた要因として, 前述の反発係数と摩擦損失に加え, 球殼車輪がアクリル材であったため, 衝突時の 球殼車輪の弾性変形により衝撃が吸収されたことや球殼内面と支柱上端にできた微小隙間により衝突振動が発生 したことなどが考えられる．跳躍高さ自体について言えば，ロボット本体直径 $0.2 \mathrm{~m}$ であるのに対して，その 2 倍以上の跳躍が可能となり, 同原理の跳躍ロボットと比べて良好な結果であった. 球殼車輪による球形ロボット の場合，車輪型などと異なり球殼内部の機構をほぼすべて衝突質量として利用できるため，このような結果が得 られたと考えられる.

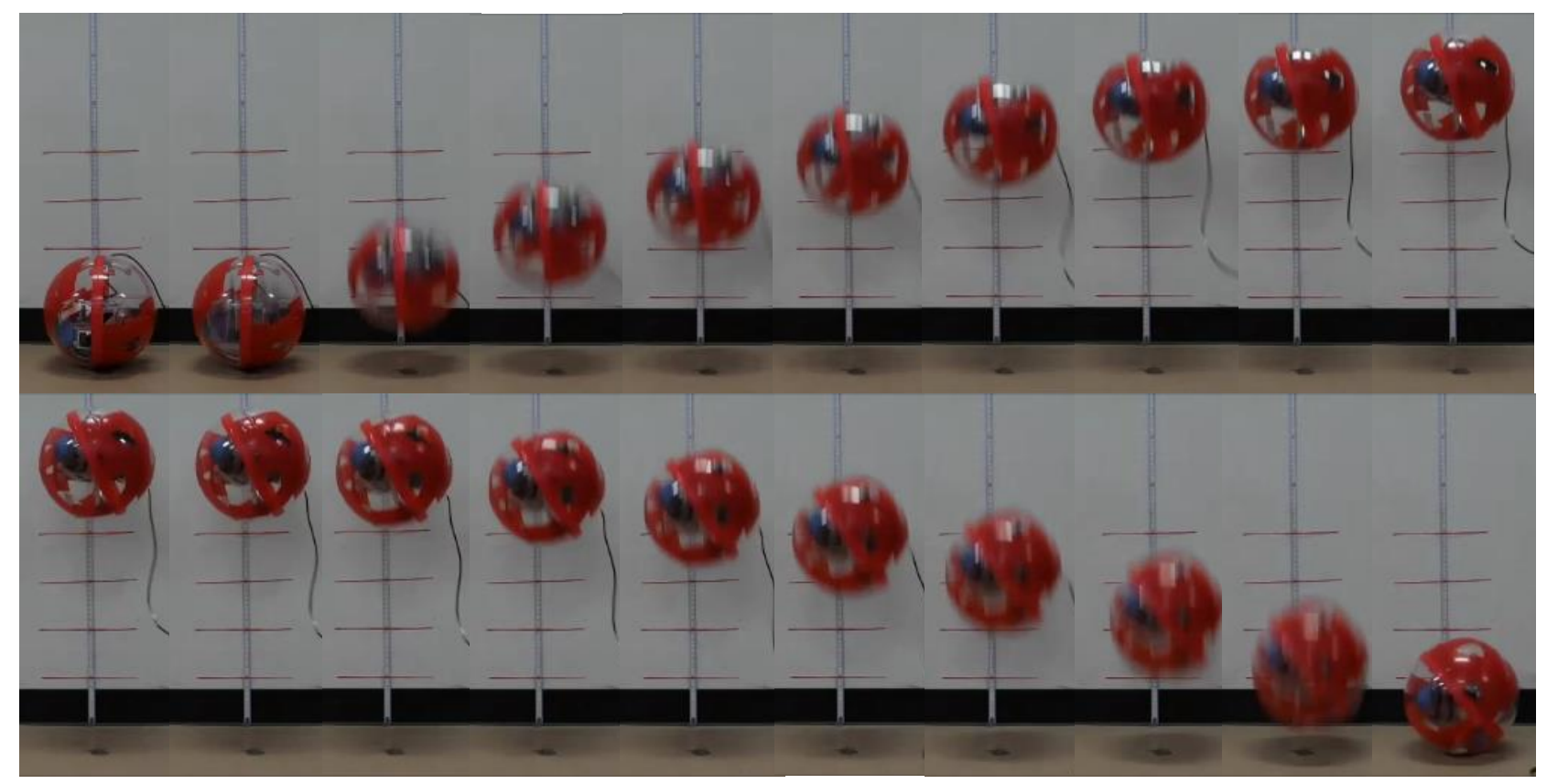

Fig. 12 Motion of vertical jumping of the spherical robot $(0.35 / \mathrm{s})$ 


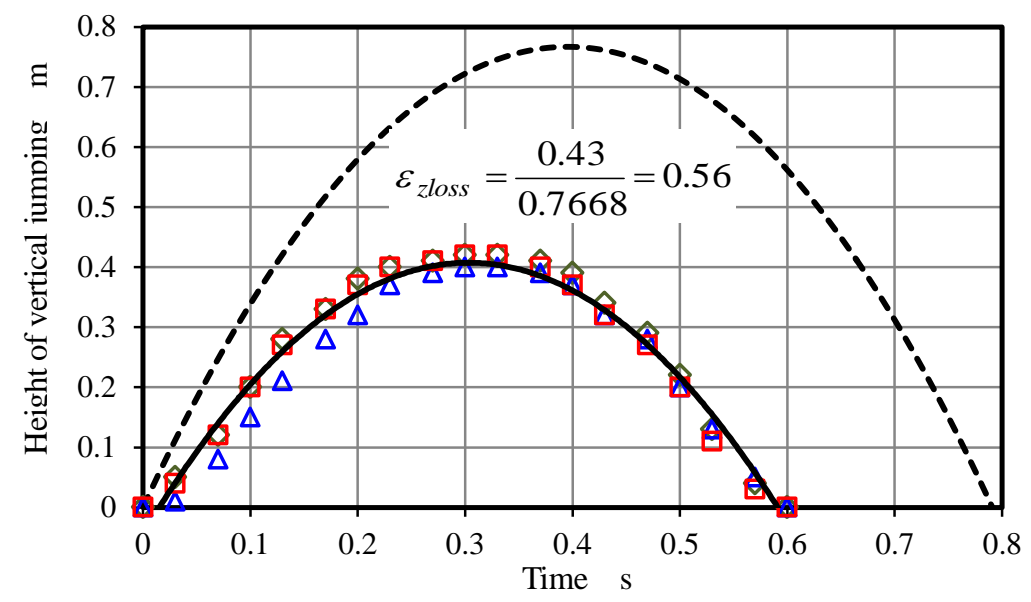

Fig. 13 Results of vertical jumping. Experimental orbits of the centroid of the robot are plotted with square dots, diamond dots and triangle dots. An approximate quadratic curve of their orbits is plotted with solid line, and theoretical orbit is plotted with the dotted line.

\section{$4 \cdot 3$ 斜方跳躍動作による障害の飛び越え}

斜方跳躍動作の確認のため, 同床面上においた状態から跳躍角度を変えて跳躍させ軌道を確認した. 跳躍角度 $\theta_{x 1 \text { end }}+\theta_{x 2 \text { end }}$ は $0.1651,0.2449,0.2914 \mathrm{rad} の 3$ 通りで行った. 跳躍時の様子を撮影し, 球殸車輪の中心座標の $z$ 軸方向および $y$ 軸方向の座標を $0.025 \mathrm{~s}$ 間隔で記録した. 各跳躍軌道の計算值と実験值を図 14 に示寸. 鉛直跳躍 の結果と同様, 跳躍量は計算值の 53〜 56\%に留まるものであったが, 安定して跳躍高さ $0.4 \mathrm{~m}$, 飛距離 $0.4 \sim 0.6 \mathrm{~m}$ を実現することできた. また実際の屋内での障害物乗り越えを想定した斜方跳躍動作の様子を図 15 に示す. 障害 物として, 屋内の一般的な階段高さに基づき, 1 段の高さが $0.185 \mathrm{~m}$, 奥行き $0.280 \mathrm{~m}$ の全 2 段の階段を設定し, その乗り越え（階段上昇）を行った. 各過程は単発の斜方跳躍と同様の条件とし, 跳躍姿勢は $0.2449 \mathrm{rad}$ を目標 值とした．今回，跳躍中の姿勢についてモデル化し，式（10），(11）より計算值を求めたが，一段目の着地時に 球殼車輪がバウンドし (図 15(a)), さらに転がることでその着地位置と姿勢が計算值から大きくずれる結果とな った. よって本報では, 二段目の跳躍に関する位置・姿勢の調整に関してのみ手動操作で行うこととした (図 15(b) 区間). 本実験結果より, 完全な自律化には至らなかったものの, 本機構が球体ロボットにおける階段上昇や障害 物の乗り越えに有効であることが実証された。

\section{5. 結 言}

球形を保った状態で回転跳躍移動が可能な移動機構を開発し，その動作について確認と検証を行った．以下に 結果を示す.

（1）球殼内部の移動機構自体を衝突慣性として利用することで，球形を保った状態で全方向に移動，跳躍が可能 な回転跳躍移動体を開発した.

（2）本移動体の直進走行および旋回動作が，球形ロボットの側面および上面からの二次元モデルに則しており, 各動作について制御可能であることを示した.

（3）球殼型の球体ロボットにおける垂直跳躍動作の原理を示し，それに基づく跳躍量の計算と実験を行い，跳躍 動作の確認と検証を行った，実際の跳蹋量は計算值の 56\%に留まるものであったが，同原理による従来の跳躍口 ボットと比べても高い跳躍高さを得ることができた.

(4) 本移動体における斜方跳躍のプロセスを提案し, 実際に実験を行い, 斜め方向に跳躍高さ $0.4 \mathrm{~m}$, 飛距離 $0.6 \mathrm{~m}$ の跳躍が可能であることを確認した. また前進（後退）動作における内部機構の傾斜を意図的に実現させること で, 跳躍角度を調整可能であることを示した. 以上の手法により斜方跳躍を連続することで, 一般的な階段の昇 降等が可能であることが確認できた。 
Fujioka, Nakamura and Seki, Transactions of the JSME (in Japanese), Vol.82, No.833 (2016)

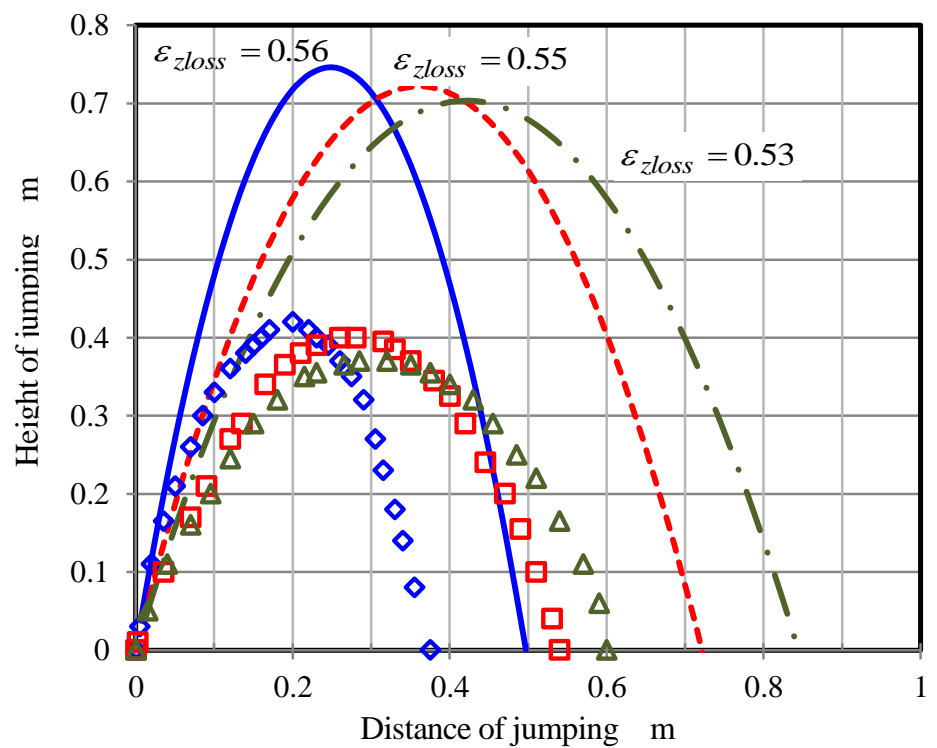

Fig. 14 Experimental results and simulation results of jumping in oblique direction. Experimental orbits of the centroid of the robot of each angle are plotted with square dots, diamond dots and triangle dots respectively. Their theoretical orbits are plotted with solid line, dotted line, and dashed line respectively.
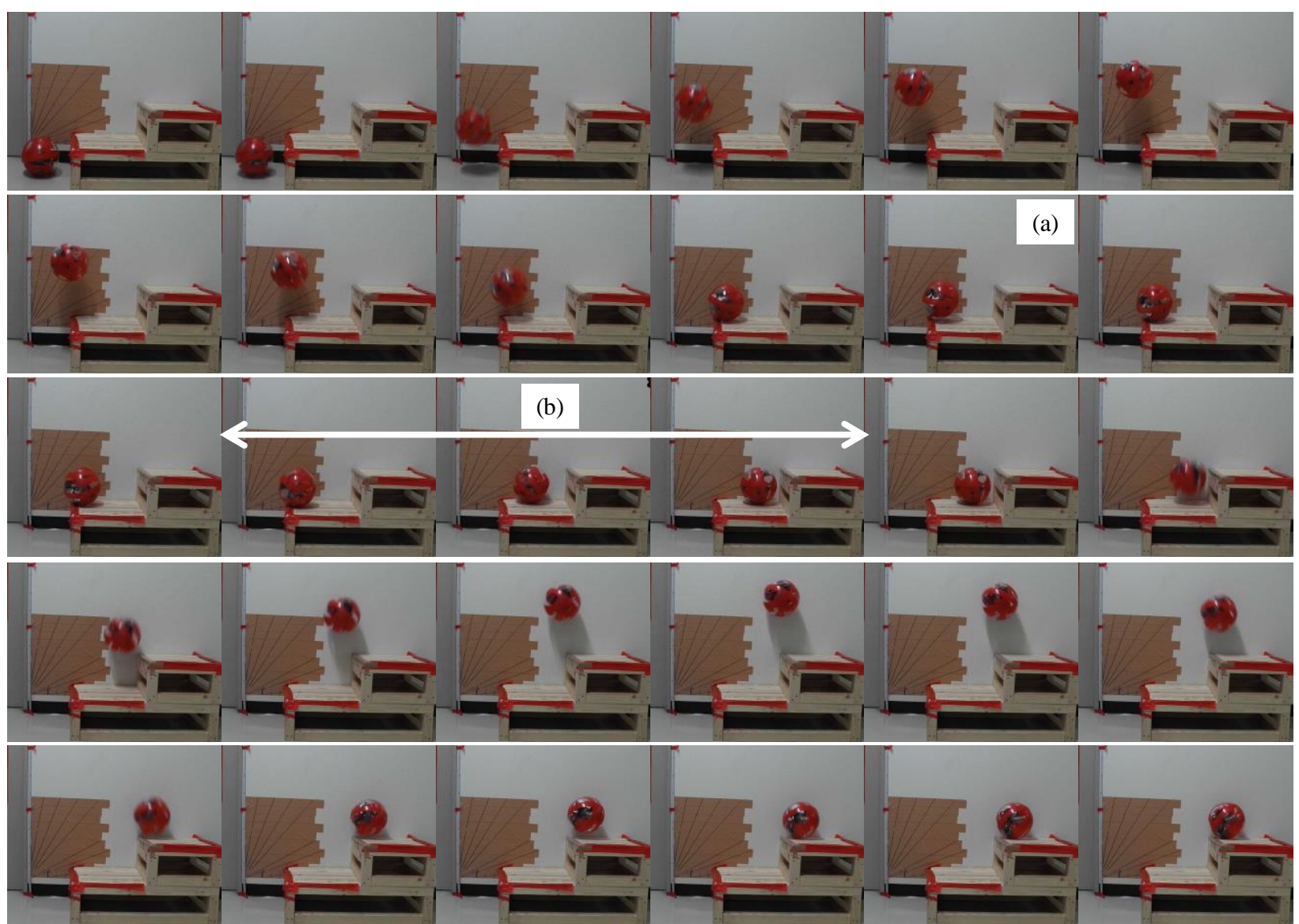

Fig. 15 Experimental result of stepping the stares at intervals of 0.05s. Bounce on the landing is shown in fig(a). The robot was controlled by radio control during the section of (b) for 3 minutes. 


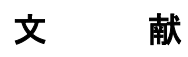

Halme, A., Schonberg, T. and Yan, W., Motion control of a spherical mobile robot, Proceedings of IEEE 4th International Workshop on Advanced Motion Control, Vol.1 (1996), pp.259-264.

市川広大, 村田将之, 佐藤雅紀, アミール A. F. ナシライ, 石井和男, 1A1-D27 跳躍機構を有する球型移動ロボッ トの開発，ロボティクス・メカトロニクス講演会講演概要集 2006 (2006), pp.1A1-D27(1)-1A1-D27(4).

㐘池 耕生, 神野 雅哉, 千島 尚也, 佐藤 健二, 2 自由度振動系を利用した低衝撃高速階段昇降に関する研究 : 運動方程式を利用したソフトランディングポイントの存在性に関する考察，日本設計工学会誌，Vol.48, No.9 (2013), pp.43-48.

越山篤, 藤井邦英, 有田恒一郎, 全方向型移動ロボットの制御に関する研究:第 4 報, 日本機械学会論文集 C 編, Vol.62, No.602 (1996), pp.55-63.

中村仁彦, 下田真吾, 庄司真史, 磁気浮上を利用した微小重カローバ, Journal of the Robotics Society of Japan, Vol.19, No.4 (2001), pp.485-491.

Ribski, P. E., Burt, I., Dahlin, T., Gini, M., Hougen, D. F., Krantz, D. G., Nageotte, F., Papanikolopoulos, N. and Stoeter, S. A., System architecture for versatile autonomous and teleoperated control of multiple miniature robots, Proceedings 2001 IEEE International Conference on Robotics and Automation, Vol.3 (2001), pp.2917-2922.

佐藤文幸, 球形飛行体の概要, 自動車技術, Vol.66, No.3 (2012), pp.102-103.

杉山勇太，平井慎一，柔軟ロボットの変形を用いた移動と跳躍, Journal of Robotics Society of Japan, Vol.24, No.3 (2006), pp.378-387.

塚越秀行, 森庸太郎, 佐々木正志, 北川能, 田中崇裕, 瓦磎踏破能力を向上させる跳躍・回転移動体の開発，日本機 械学会論文集 C 編, Vol.70, No.692 (2004a), pp.180-188.

塚越秀行，佐々木正志，北川能，田中崇裕，瓦礫跳躍高度の向上を目指した空圧ジャンピングの特性解析，計測自 動制御学会論文集, Vol.40, No.8 (2004b), pp.859-866.

塚越秀行, 田中崇裕, 木村大地, 北川能, 1P2-S-096 倒壊家屋内での広域探索を目指した投橂・回収型移動体の開 発 :第 2 報，ロボティクス・メカトロニクス講演会講演概要集 2005 (2005), pp.1P2-S-096.

\section{References}

Halme, A., Schonberg, T. and Yan, W., Motion control of a spherical mobile robot, Proceedings of IEEE 4th International Workshop on Advanced Motion Control, Vol.1 (1996), pp.259-264.

Ishikawa, K., Murata, M., Sato, M., Nassiraei, A. A. F. and Ishii, K., 1A1-D27 Development of a ball type mobile robot equipped with a jump actuator, Proceedings JSME Conference on Robotics and Mechatronics 2006 (2006), pp.1A1-D27(1)-1A1-D27(4) (in Japanese).

Kikuchi, K., Jinno, M., Chishima, N. and Sato, K., A study on fast stair-climbing and soft-landing by 2-DOF hopping mechanism : Analysis of soft-landing point existence using equation of motion, Journal of Japan Society for Design Engineering, Vol.48, No.9 (2013), pp.43-48 (in Japanese).

Koshiyama, A., Fujii, K. and Arita, K., Development and motion control of an all-direction steering-type mobile robot : 4th report, Transactions of the Japan Society of Mechanical Engineers, Series C, Vol.62, No.602 (1996), pp.55-63 (in Japanese).

Nakamura, Y., Shimoda, S. and Shoji, S., Microgravity rover using electro-magnetic actuation, Journal of the Robotics Society of Japan, Vol.19, No.4 (2001), pp.485-491 (in Japanese).

Ribski, P. E., Burt, I., Dahlin, T., Gini, M., Hougen, D. F., Krantz, D. G., Nageotte, F., Papanikolopoulos, N. and Stoeter, S. A., System architecture for versatile autonomous and teleoperated control of multiple miniature robots, Proceedings 2001 IEEE International Conference on Robotics and Automation, Vol.3 (2001), pp.2917-2922.

Sato, F., Overview of spherical air vehicle, Journal of Society of Automotive Engineers of Japan, Vol.66, No.3 (2012), pp.102-103 (in Japanese).

Sugiyama, Y. and Hirai, S., Soft robots for crawling and jumping via deformation, Journal of Robotics Society of Japan, Vol.24, No.3 (2006), pp.378-387 (in Japanese).

Tsukagoshi, H., Mori, Y., Sasaki, M., Tanaka, T. and Kitagawa, A., Development of a jumping \& rolling inspector to improve the debris-traverse ability, Transactions of the Japan Society of Mechanical Engineers, Series C, Vol.70, No.692 (2004a), pp.180-188 (in Japanese).

Tsukagoshi, H., Sasaki, M., Tanaka, T. and Kitagawa, A., Numerical analysis and design for higher jumping on debris using a 
Fujioka, Nakamura and Seki, Transactions of the JSME (in Japanese), Vol.82, No.833 (2016)

pneumatic cylinder, Transactions of the Society of Instrument and Control Engineers, Vol.40, No.8 (2004b), pp.859-866 (in Japanese).

Tsukagoshi, H., Tanaka, T., Kimura, D. and Kitagawa, A., 1P2-S-096 Development of a throwing \& drawing type inspector aimed to wide-range searching inside collapsed buildings : 2nd report, Proceedings JSME Conference on Robotics and Mechatronics 2005 (2005), pp.1P2-S-096 (in Japanese). 